\title{
ロータス型ポーラス $\mathrm{Ni}_{3} \mathrm{Al}$ 金属間合物の作製*
}

\section{玄 丞均 池田輝之 中嶋英雄}

\author{
大阪大学産業科学研究所
}

J. Japan Inst. Metals, Vol. 68, No. 2 (2004), pp. 39-42 (C) 2004 The Japan Institute of Metals

\section{Fabrication of Lotus-type Porous $\mathrm{Ni}_{3} \mathrm{Al}$ Intermetallics}

Soong-Keun Hyun, Teruyuki Ikeda and Hideo Nakajima

The Institute of Scientific and Industrial Research, Osaka University, Ibaraki 567-0047

Lotus-type porous $\mathrm{Ni}_{3} \mathrm{Al}$ intermetallics ( $\mathrm{Ni}-15 \mathrm{~mol} \% \mathrm{Al}, \mathrm{Ni}-28 \mathrm{~mol} \% \mathrm{Al}$ and $\mathrm{Ni}-31 \mathrm{~mol} \% \mathrm{Al}$ ) whose long cylindrical pores are aligned in one direction have been fabricated by unidirectional solidification of the melt in a pressurized hydrogen gas. The porosity and the pore size are decreased with increasing aluminum content. An increase of solidification velocity from 0.33 to 0.50 $\mathrm{mms}^{-1}$ leads to a decrease of pore diameter and an increase of pore number in lotus-type porous $\mathrm{Ni}-28 \mathrm{~mol} \% \mathrm{Al}$.

(Received November 10, 2003; Accepted December 3, 2003)

Keywords: porous materials, intermetallics, nickel aluminide, solidification, porosity

\section{1. 概 要}

近年，開発されたロータス(レンコン)型ポーラス金属は， 多数の平行な円柱状の微細孔(数 $10 \mu \mathrm{m} \sim$ 数 $\mathrm{mm}$ )を有し, 従 来のポーラス金属より優れた機械的特性をもつ画期的な金属 材料として注目されている1-10). ロータス型ポーラス金属 は，構造的に優れた曲げおよびネジリ強度を持つ5)ことを利 用した高温軽量構造材料, 巨大な表面積を利用した高温触 媒，多孔性を利用した高温フィルター，さらには，制振性や 吸音性, 耐衝撃性を利用した高温部材等, その応用性は幅広 い.

ロータス型ポーラス金属の作製原理は，溶融状態からの一 方向凝固時における過飽和ガス原子の析出により生成する気 泡を金属内に一方向に生成させるものである.すなわち, 溶 融金属におけるガス原子の溶解度が大きく, その固体金属中 での固溶度が小さい場合, 凝固時に固溶しきれないガス原子 が気泡(ポア)を形成することを利用している，このような溶 解度ギャップは凝固の際の多量のガス放出を意味し, 気泡の 生成原因となる，実際に，ポーラス化できる金属は，水素雾 囲気では, 鉄, ニッケル, アルミニウム, 銅, マグネシウ ム, コバルト, タングステン, マンガン, クロム, ベリリウ ム, チタンとそれらの合金であり, 酸素雾囲気では, 銀, 金 とその合金である。さらに, 爆発性がない安全な窒素雾囲気 でも鉄, 鉄合金, ステンレス鋼抢よび鋳鉄などの金属をポー ラス化することができる11).

一方，金属間化合物は，高温強度，耐酸化性，耐食性に優 れた材料であり, もし気泡を一方向に揃えて多孔質化できれ

* 2003 年 10 月 12 日日本金属学会秋期大会において発表
ば, 高温軽量構造材料や高温触媒担体, 高温フィルターなど への応用が期待できる. 特に, アルミナイド系金属間化合物 は, 超合金や耐熱鋼に比べて密度が低いために高温材料の軽 量化材料として注目されている(2-14)。我々は，これらを ポーラス化することにより更に軽量化が期待できることに着 目した．そこで, 本研究では, 一方向性微細孔を有するロー タス型ポーラス $\mathrm{Ni}_{3} \mathrm{Al}$ 金属間化合物を含むいくつかの組成の $\mathrm{Ni}-\mathrm{Al}$ 合金の創製を試み, 高温軽量材料への可能性を調べる ことを目的とした. なお, 本研究は, ロータス型ポーラス金 属間化合物の創製を行なった最初の研究である.

\section{2. 実 験 方 法}

$\mathrm{Ni}_{3} \mathrm{Al}$ 金属間化合物の原料棒を作製するために, 純度 99.9\%の電解ニッケルと純度 $99.99 \%$ のアミニウムをアル ミナるつぼに入れ, アルゴン $0.3 \mathrm{MPa}$ の雾囲気で高周波溶 解 ·凝固させて合金化した。アルゴンガスの純度は 99.999\%である. 得られたインゴットは, 放電加工機 (Model A320D, Sodick Co.)により, 直径 $10 \mathrm{~mm}$, 高さ 100 $\mathrm{mm}$ の棒材に切り出した. 棒材を高さ方向に $10 \mathrm{~mm}$ 間隔で 切出し, それぞれの密度を測定した結果, 密度がほぼ一定で あり，均質な原料棒が作製できた。

この棒材は, 水素ガス圧 $2.5 \mathrm{MPa}$ の雾囲気中で Fig. 1 の ような連続帯溶融法11)で一方向凝固させた. 水素ガスの純 度は $99.999 \%$ であ. 上部と下部に高温で安定なグラファ イトを用いて固定した棒材は, 直径 $20 \mathrm{~mm}$ の高周波コイル の中央を通るように鉛直に保持しながら下方向に $330 \mu \mathrm{m}$ $\mathrm{s}^{-1}$ あるいは $500 \mu \mathrm{m} \mathrm{s}^{-1}$ の一定の速度で移動させた．ロー タス型ポーラス金属間化合物を作製する際には, 原料棒を部 分的に加熱させつつ移動させることにより連続的に溶解, 凝 


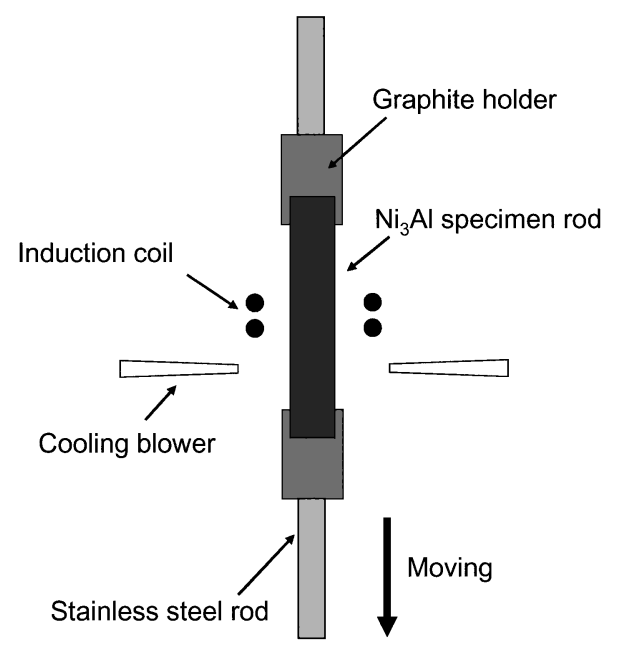

Fig. 1 Schematic drawing of the fabrication process for lotustype porous $\mathrm{Ni}_{3} \mathrm{Al}$ intermetallics.

固させた．また，コイル下部にブロワーを設置し，容器内の ガスを循環させ試料に吹き付けて強制冷却した. 装置の外側 には放射温度計(東京精工株式会社製炉内温度監視装置)を設 置し，凝固界面付近の温度分布を二次元的に測定した。

得られたロータス型ポーラス金属間化合物は, ワイヤーカ ット放電加工機で切出し, 光学顕微鏡 (KEYENCE 社製デシ タル HD マイクロスコープ VH-7000)を用いてポア形状を 観察し，画像解析ソフト (三谷商事株式会社製 Mac SCOPE) を用いてポアの占める面積率より, その断面でのポロシティ を算出した. また, 凝固方向と平行な試料面をエメリ一紙の 2000 番まで機械研磨し, 粒径 $1 \mu \mathrm{m}$ のダイヤモンド粒子を 用いてバフ研磨した後にミクロ組織観察を行なった. エッチ ング液には, $5 \mathrm{~g} \mathrm{CuSO}_{4}, 20 \mathrm{ml} \mathrm{HCl}, 20 \mathrm{ml} \mathrm{H}_{2} \mathrm{O}$ の溶液を用い た. 粉末 X 線回折 (理学電機株式会社製 MJ200KE 型) 抢よ び電子線マイクロアナライザ (日本電子株式会社製 JXA8800R 型)を用いて相分析と定量分析を行なった.

\section{3. 結 果と考 察}

Table 1 には，作製したロータス型ポーラス $\mathrm{Ni}-\mathrm{Al}$ 合金の 定量分析結果を示す. $\mathrm{Ni}+\mathrm{Ni}_{3} \mathrm{Al}$ の組織で $\mathrm{Ni}$ 基超合金とし て用いられる15)組成に近い $\mathrm{Ni}-15 \mathrm{~mol} \% \mathrm{Al}$ (以下に $\mathrm{mol} \%$ は 省略), アルミニウムリッチの $\mathrm{Ni}_{3} \mathrm{Al}$ 金属間化合物に近い $\mathrm{Ni}-28 \mathrm{Al}$, さらにアルミニウム量を増やした $\mathrm{Ni}-31 \mathrm{Al}$ を作製 した.これらの試料の粉末 X 線回折の測定結果を Fig. 2 に 示す. $\mathrm{Ni}-15 \mathrm{Al}$ の場合, $\mathrm{Ni}$ と $\mathrm{Ni}_{3} \mathrm{Al}$ の相が観測され, $\mathrm{Ni}-$ $28 \mathrm{Al}$ の場合, $\mathrm{Ni}_{3} \mathrm{Al}$ のみ, $\mathrm{Ni}-31 \mathrm{Al}$ の場合, $\mathrm{Ni}_{3} \mathrm{Al}, \mathrm{Ni}_{5} \mathrm{Al}_{3}$, $\mathrm{NiAl}$ の相が同定された. Fig. 3 に水素圧 $2.5 \mathrm{MPa}$, 移動速 度 $330 \mu \mathrm{m} \mathrm{s}^{-1}$ で作製したロータス型ポーラス $\mathrm{Ni}-28 \mathrm{Al}$ の凝 固方向に平行な断面の顕微鏡写真を示す。原料棒に比べて ポーラス部分の方が脹らみ, 円筒状のポアが凝固方向と同じ 方向に成長した高さ約 $50 \mathrm{~mm}$ の均一なロータス型ポーラス $\mathrm{Ni}_{3} \mathrm{Al}$ 金属間化合物が作製できた.

Fig. 4 はロータス型ポーラス $\mathrm{Ni}_{3} \mathrm{Al}$ 金属間化合物のポア成 長方向に垂直に切断した横断面の写真である. 水素圧 2.5
Table 1 Chemical composition of lotus-type porous $\mathrm{Ni}_{3} \mathrm{Al}$ intermetallics.

\begin{tabular}{ccc}
\hline & $\mathrm{Al}(\mathrm{mol} \%)$ & Deviation $(\mathrm{mol} \%)$ \\
\hline $\mathrm{Ni}-15 \mathrm{Al}$ & 15.4 & \pm 0.174 \\
\hline $\mathrm{Ni}-28 \mathrm{Al}$ & 27.9 & \pm 0.792 \\
\hline $\mathrm{Ni}-31 \mathrm{Al}$ & 31.3 & \pm 0.357 \\
\hline
\end{tabular}

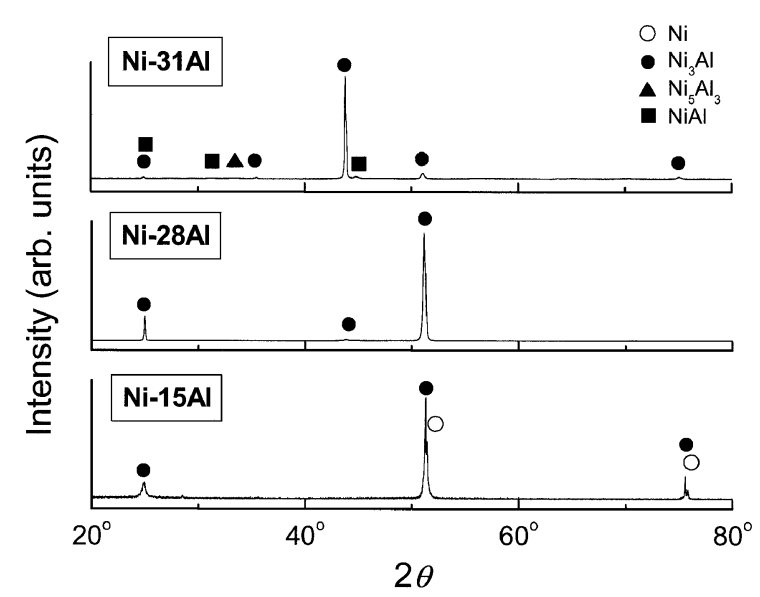

Fig. 2 X-ray diffraction pattern of lotus-type porous $\mathrm{Ni}_{3} \mathrm{Al}$ intermetallics cross-sectioned in the direction perpendicular to pore axis.

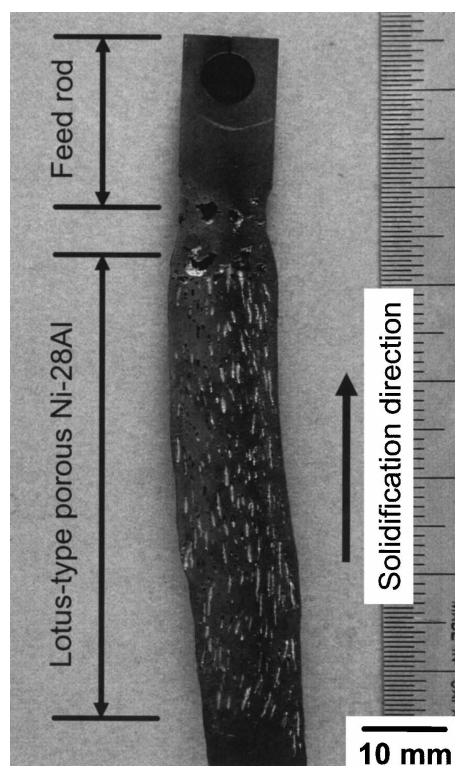

Fig. 3 Optical Micrograph of lotus-type porous $\mathrm{Ni}-28 \mathrm{Al}$ in parallel section to solidification direction.

$\mathrm{MPa}$, 移動速度は $330 \mu \mathrm{m} \mathrm{s}^{-1}$ で一定である. $\mathrm{Ni}-15 \mathrm{Al}$ の場 合にはポア形態はほぼ円形であったのに対して, Ni-28Al と Ni-31Al では, 多くのポアがいびつな形態になっている. $\mathrm{Ni}-15 \mathrm{Al}$ と $\mathrm{Ni}-28 \mathrm{Al}$ の凝固方向に平行な縦断面の凝固組織 を Fig. 5 に示す. Ni-28Al の場合にデンドライトの組織が 観察され, デンドライト間隙で核生成したポアが成長する際 に, デンドライトアームに接し, 円形の断面を保って真直ぐ 成長できず，いびつな断面形態になったと考えられる。これ 


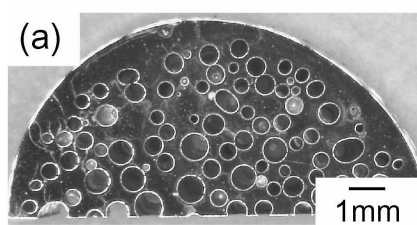

(d)

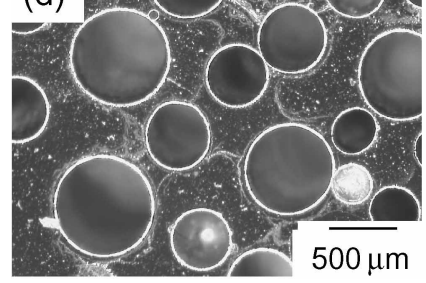

(b)

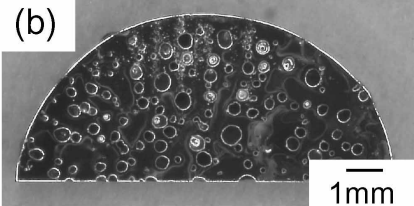

(e)

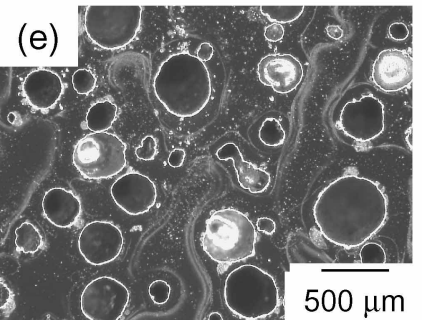

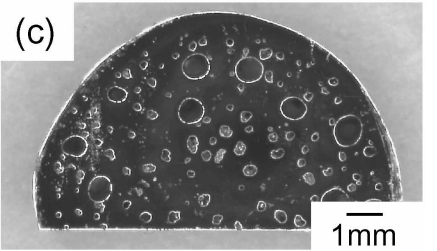

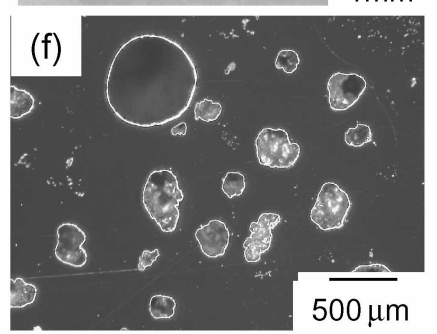

Fig. 4 Optical Micrographs of lotus-type porous (a), (d) Ni-15Al, (b), (e) Ni-28Al and (c), (f) Ni-31Al in perpendicular section to solidification direction.
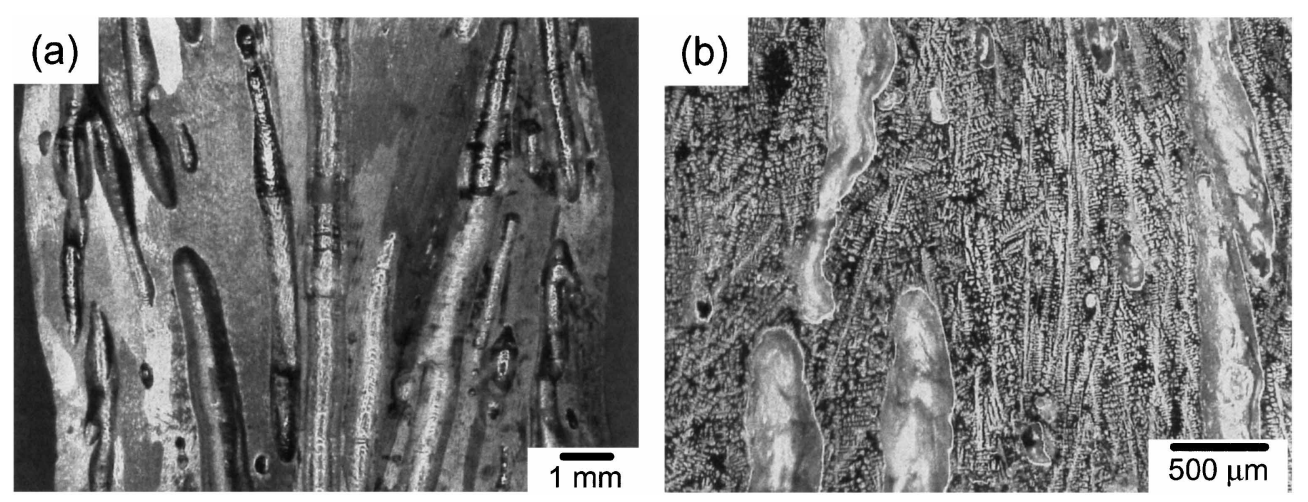

Fig. 5 Optical micrographs of lotus-type porous (a) $\mathrm{Ni}-15 \mathrm{Al}$ and (b) $\mathrm{Ni}-28 \mathrm{Al}$ in parallel section to solidification direction.

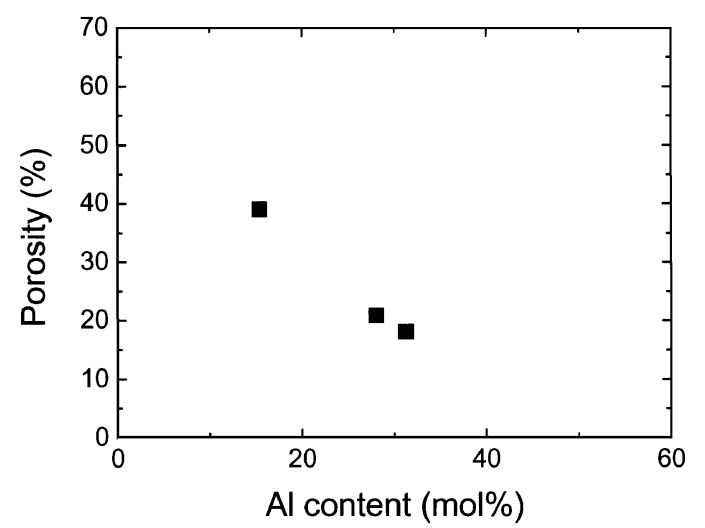

Fig. 6 Porosity of lotus-type porous $\mathrm{Ni}_{3} \mathrm{Al}$ intermetallics as a function of $\mathrm{Al}$ content.

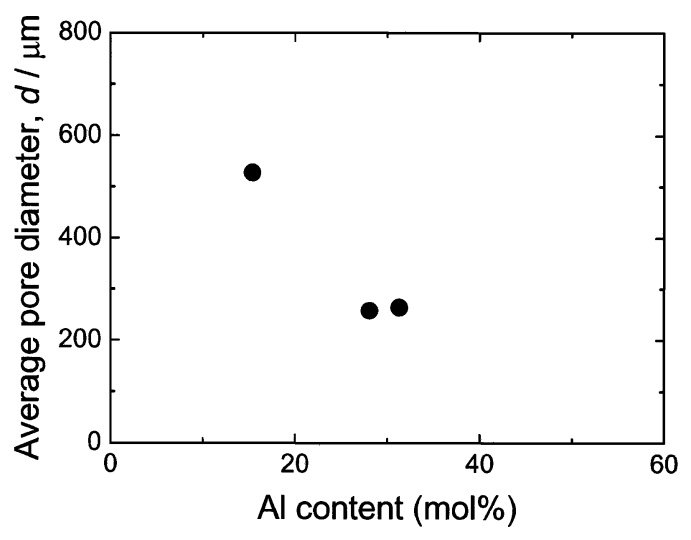

Fig. 7 Average pore diameter of lotus-type porous $\mathrm{Ni}_{3} \mathrm{Al}$ intermetallics as a function of $\mathrm{Al}$ content.
に対して，Ni-15Al の組織ではデンドライトは観察されず, 滑らかにポアが成長した。これは, Ni-15Al の場合, $\mathrm{Ni}-\mathrm{Al}$ 系の平衡状態図に見られるように固液共存領域が狭いため, デンドライトアームが発達しにくく, Ni-28Al のようにポア 成長に影響しなかったためだと考えられる。

ロータス型ポーラス $\mathrm{Ni}-\mathrm{Al}$ 合金のポロシティと平均ポア 径に及ぼすアルミニウム含量の影響をそれぞれ Fig. 6 打よ び Fig. 7 に示す.アルミニウムの濃度の増加と共にポロシ
ティが低下する傾向が見られる，ロータス型ポーラス金属の ポロシティは, 凝固時に固体金属で過飽和になった水素ガス 量と直接関係がある ${ }^{16)}$. 固液界面ではき出された水素は, ポアを生成し, 同じ全圧下ではポロシティははき出された水 素の量に比例する. ニッケルにアルミニウムを添加すると, 液相中の水素溶解度は低下することが Lange らによって報 告されている17). 例えば，水素厓 $0.1 \mathrm{MPa}$ の下で温度 1773 $\mathrm{K}$ に抢ける $\mathrm{Ni}-25 \mathrm{Al}$ の水素溶解度は, 純ニッケルに比べ, 

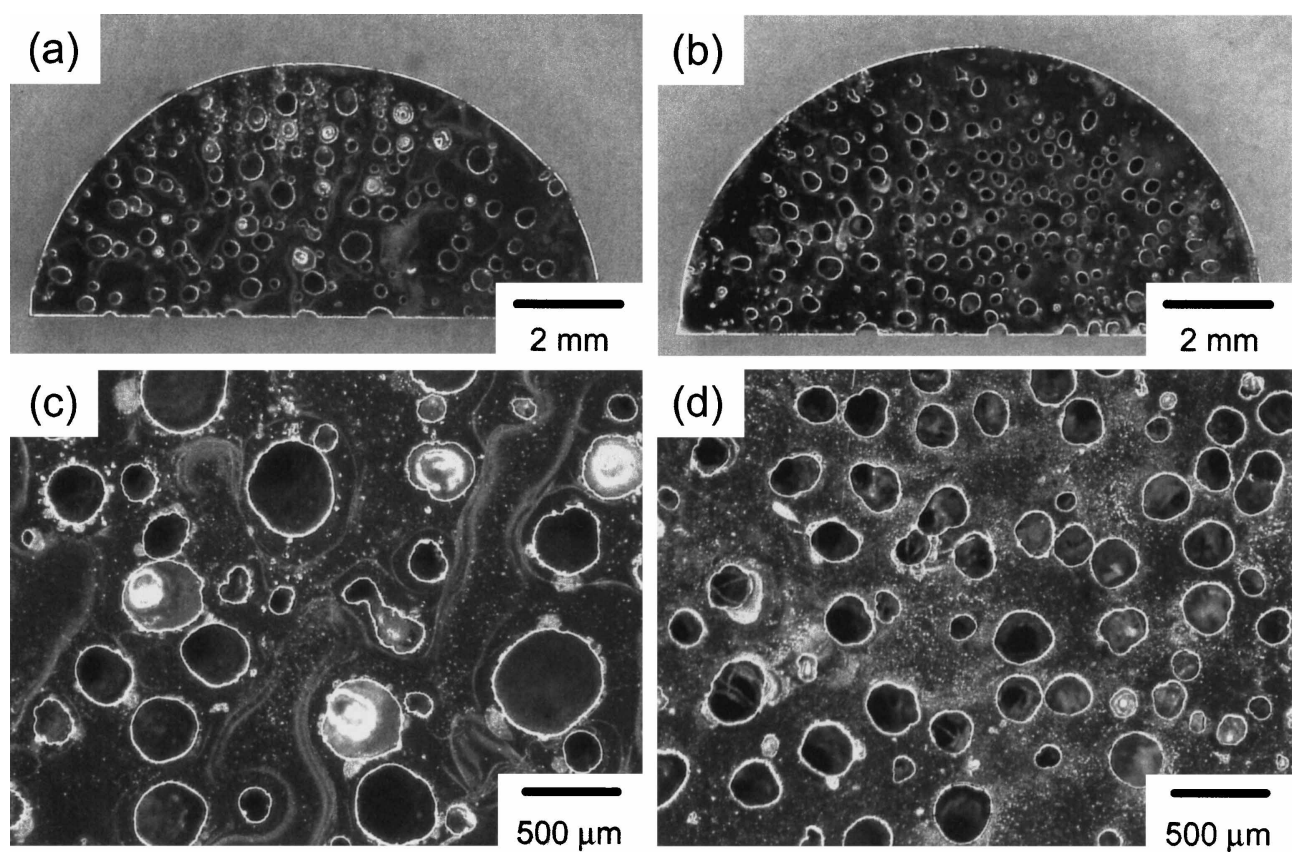

Fig. 8 Optical micrographs of lotus-type porous $\mathrm{Ni}-28 \mathrm{Al}$ solidified with solidification rate of (a), (c) $330 \mu \mathrm{m} \mathrm{s}^{-1}$ and (b), (d) 500 $\mu \mathrm{m} \mathrm{s}^{-1}$.

約 0.5 倍に減少する.したがって，合金元素であるアルミニ ウム濃度の増加と共に, 溶融合金中の水素溶解度が減少し, 凝固する際にポアを形成する水素量が減少したため, ポロシ ティが低下したことが分かる，一方，デンドライトの影響を 無視すると, 平均ポア径も, アルミニウムの増加と共に水素 溶解度の減少により，ポアを形成する水素量の減少に伴っ て，減少したと考えられる.

Fig. 8 には, 水素 $2.5 \mathrm{MPa}$ 雾囲気下で原料棒の移動速度 を $330 \mu \mathrm{m} \mathrm{s}^{-1}, 500 \mu \mathrm{m} \mathrm{s}^{-1}$ と変化させた $\mathrm{Ni}-28 \mathrm{Al}$ のポア成 長方向に垂直な断面の写真を示す。移動速度を $330 \mu \mathrm{m} \mathrm{s}^{-1}$ から $500 \mu \mathrm{m} \mathrm{s}^{-1}$ に増加させるとポア径が小さくなる。この 原因は，次のように考えられる，凝固速度と比例関係である 移動速度が速いほど過冷却温度が大きくなり，核生成できる ポアの数が増加する．ところが，溶融金属に溶解した水素量 は大きく変わらないため, 溶融域に溶け込んだ水素のうち成 長する一つのポア中に拡散して入る水素量は少なくなり, 結 果としてポア径が小さくなったと考えられる．また，デンド ライトの影響を考慮すると, 移動速度が大きくなるほどデン ドライトアーム間隙が短くなり，多数のポアが核生成し，上 記と同様にポアが小さくなった原因の一つであると考えられ る. 断面写真から観察されるポア数も, 移動速度 $500 \mu \mathrm{m}$ $\mathrm{s}^{-1}$ の方が，移動速度 $330 \mu \mathrm{m} \mathrm{s}^{-1}$ より多いので以上のこと が説明できる。この結果は，純銅18，あるいはステンレス

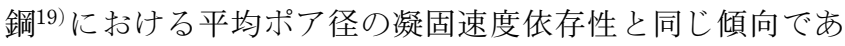
る.

\section{4. 結言}

加压水素ガス中で $\mathrm{Ni}_{3} \mathrm{Al}$ 金属間化合物を含む $\mathrm{Ni}-15 \mathrm{Al}$, $\mathrm{Ni}-28 \mathrm{Al}, \mathrm{Ni}-31 \mathrm{Al}$ の棒材を一方向凝固させることによっ て，平行な多数の円柱状ポアを有するロータス型ポーラス
$\mathrm{Ni}-\mathrm{Al}$ 合金を作製することができた．アルミニウム含量が増 加するとポロシティおよびポア径は減少する傾向が見られ た．こ机は, アルミニウム増加と共に, 溶融金属の水素溶解 度が減少したためであると考兄られる。また，Ni-28Alにお いて移動速度が大きいほどポア径が小さくなった。

本研究は文部科学省産学官連携イノベーション創出事業費 補助金抢よび 21 世紀 COE プログラム「構造・機能先進材 料デザイン研究拠点形成」の研究費によって行なわれたもの である。

文献

1) J. Banhart and D. Weaire: Phys. Today 55(2000) 37-42.

2) H. Nakajima: Mater. Integration 12 (1999) 37-44.

3) H. Nakajima: The Production \& Tech. 51(1999) 60-62.

4) H. Nakajima: Boundary 15(1999) 9-11.

5) H. Nakajima: Funct. Mater. 20(2000) 27-34.

6) H. Nakajima: Bull. Iron Steel Inst. Jpn. 6 (2001) 701-707.

7) H. Nakajima, S. K. Hyun, K. Ohashi, K. Ota and K. Murakami: Colloid. Surface. A 179(2001) 209-214.

8) S. K. Hyun and H. Nakajima: Mater. Trans. 43(2002) 526-531.

9) S. K. Hyun, K. Murakami and H. Nakajima: Mater. Sci. Eng. A 299 (2001) 241-248.

10) S. K. Hyun and H. Nakajima: Mater. Sci. Eng. A 340(2003) 258-264.

11) H. Nakajima, T. Ikeda and S. K. Hyun: Proc. $3^{r d}$ Int. Conf. on Cellular Metals and Metal Foaming Technology, (MIT Verlag, Berlin), in press.

12) T. Hirano: Acta Metall. Mater. 38(1990) 2667-2671.

13) M. Yamaguchi, H. Inui and K. Ito: Acta Mater. 48(2000) 307322.

14) S. C. Deevi and V. K. Sikka: Intermetallics 4(1996) 357-375.

15) H. Borodianska, M. Demura, K. Kishida and T. Hirano: Intermetallics 10(2002) 255-262.

16) S. Yamamura, Y. Shiota, K. Murakami and H. Nakajima: Mater. Sci. Eng. A 318(2001) 137-143.

17) K. W. Lange and H. Schenck: Z. Metallk. 60(1969) 638-642.

18) S. K. Hyun and H. Nakajima: Mater. Lett. 57 (2003) 3149-3154.

19) T. Ikeda, T. Aoki and H. Nakajima: Tetsu-to-Hagane, in press. 